\title{
High precision laser scanning assisting in the service of historical and art historical research. The burial monument of Queen Gertrude (13th century)
}

\author{
BEATRIX SZABÓ, GÁBOR BÖDŐ, ANDRÁS FEHÉR, KONSZTANTINOSZ HADZIJANISZ, \\ RÉKA LOVAS, DÓRA SURINA, BARNABÁS VÁRI \\ Mensor 3D Ltd., Hungary \\ GYULA DABRÓNAKI, BOGLÁRKA LAKI, LÁSZLÓ PIPIS \\ Humansoft Ltd., Hungary \\ JÓZSEF LASZLOVSZKY \\ Central European University, Budapest
}

\begin{abstract}
One of the most important and controversial burial sites of medieval Hungary is the grave of Queen Gertrude of Meran with its decorated burial monument at the Cistercian Abbey of Pilis. The circumstances of her assassination are hotly debated in Hungarian history and are described in a large number of local and foreign contemporary documents. Archaeological excavations have revealed the fragments of her burial monument with high artistic qualities (human figures, architectural elements, inscriptions, decorated patterns). Over the last three decades, art historical research has discussed the foreign artistic influences of the monument and proposed several reconstructions based on the drawings and photos of the excavated fragments. A full-size sculpted model has also been created on the basis of one of these hypothetical reconstructions. This paper will present the results of a new research project to create the first virtual reconstruction of the burial monument. By using 3D technology, the results and conclusions derived from the fragments have been made more accessible than through traditional methods.
\end{abstract}

Key words:

3D reconstruction, 3D survey, database of reconstruction, 3D modeling, Tomb of Queen Gertrude.

SDH Reference:

Beatrix Szabó et al. 2017. High precision laser scanning assisting in the service of historical and art historical research. SDH, 1, 2, 501-517.

DOI : $10.14434 / \mathrm{sdh} . \mathrm{v} 1 \mathrm{i2} .23420$

Corresponding Author's address: Beatrix Szabó, Mensor 3D Ltd., 8. Montevideo Street, 1037 Budapest, Hungary; email: beatrix.szabo@humansoft.hu.

Permission to make digital or hardcopies of part or all of this work is granted without fee according to the open access policy of SDH.

(C) 2017 SDH Open Access Journal

Studies in Digital Heritage, Vol. 1, No. 2, Publication date: December 2017 
1:502 B. Szabó et al.

\section{HISTORY AND SIGNIFICANCE}

Gertrude of Andechs-Meran was a Hungarian queen, the first wife of King Andrew II (1176-1235 AD). She was born in 1185 and in 1213 was assassinated by a conspiracy of aristocrats while the king was leading a military campaign in Galicia. She was buried in the Cistercian Abbey of Pilis, ruins of which can be seen today at Pilisszentkereszt. Because her tragic story is recounted in many literary works and in the country's most important nineteenth century, she became one of the best-known Hungarian queens.

Furthermore, her burial monument represents a unique case in the history of medieval Cistercian monasteries. Not only was it the first time that a royal funeral took place in a Cistercian monastery in Hungary, but it was also without precedent that a queen was buried in a Cistercian monastery prior to any kings in a European kingdom [Laszlovszky 2016]. The sculpted elements of her sepulchre also represent the first appearance of French Gothic art in Hungary. Art historical research has also suggested links between Villard de Honnecourt, the author of the most important contemporary architectural sketchbook and probably the creator of the royal burial monument [Gerevich 1971b; Takács 2014]. This issue also clearly shows how important this monument is for the interpretation of artistic influences between different parts of thirteenth-century Europe.

\section{DESCRIPTION OF THE FINDINGS AND THE FORMER RECONSTRUCTIONS}

Sixty-five fragments have been identified by previous research as parts of the burial monument, and they are kept in the Hungarian National Gallery [Takács 2014]. There have been three major attempts to reconstruct Gertrude's tomb. The first set of reconstructions, which were used as a basis for further attempts, was made by archaeologist and art historian László Gerevich, the leader of the excavation. He had found the high quality carved and decorated fragments scattered in the transept of the church during his excavation and he linked them to the burial monument of Queen Gertrude [Gerevich 1971b] (Fig. 1).

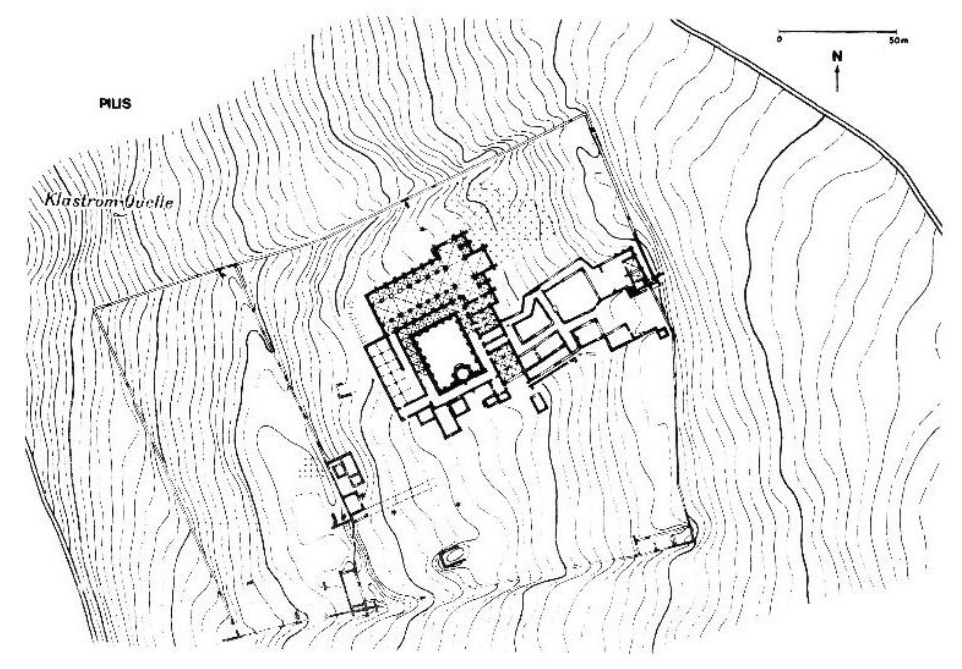

Figure 1. The excavation site plan [Gerevich 1985]. 


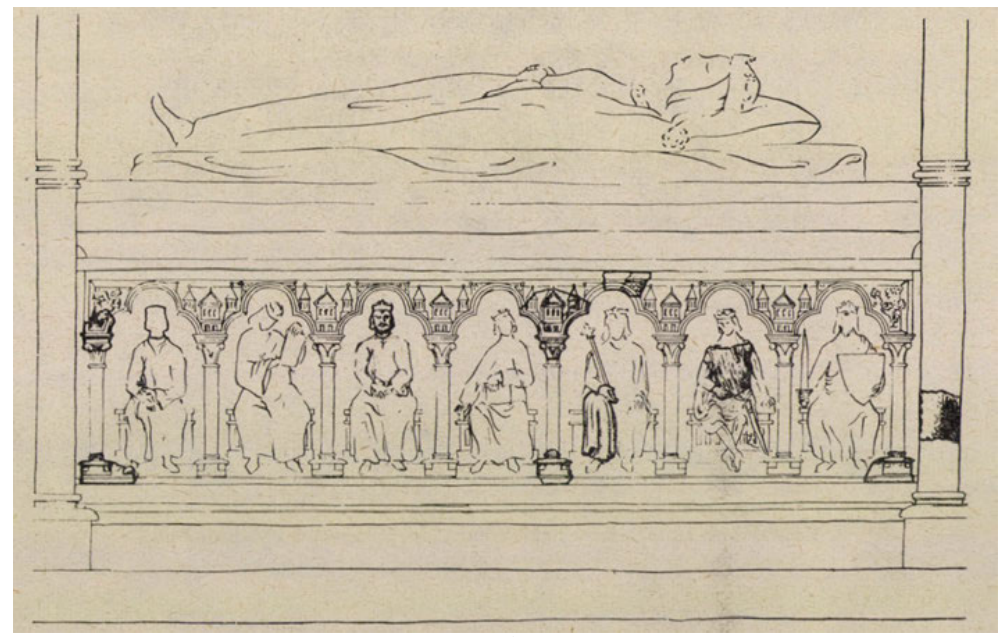

a)

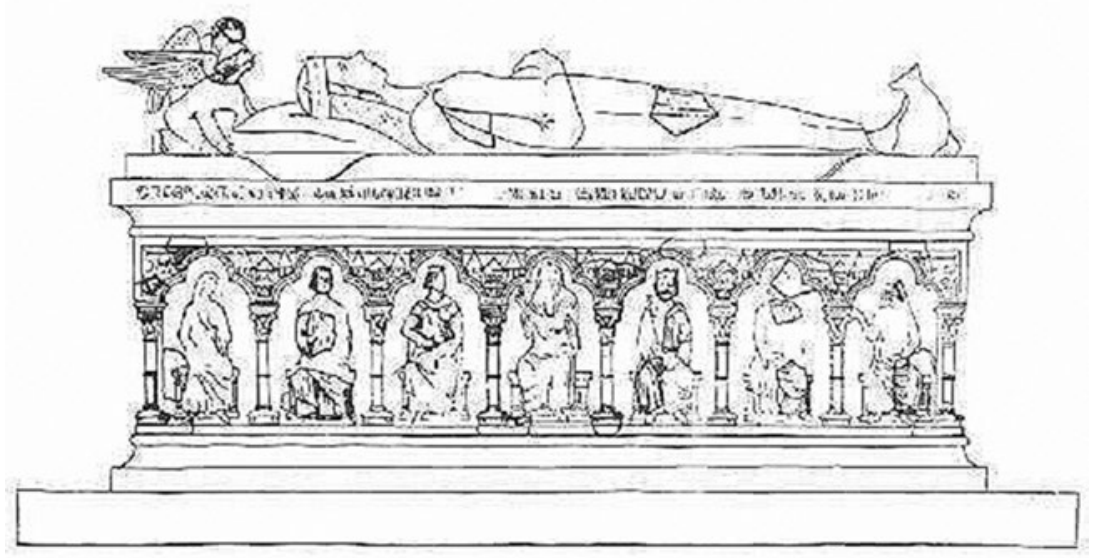

b)

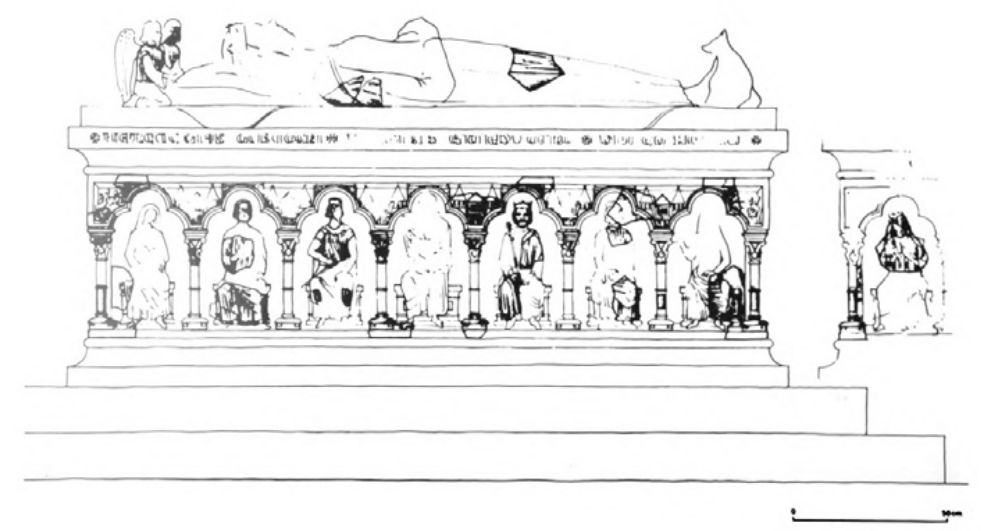

c)

Figure 2. The first attempts of reconstruction by L. Gerevich: a) 1971.b; b) 1982; c) 1983. 
International art historical research has accepted this identification and connected this sculpted grave memorial to the reconstructed burial monument of Philippe Dagobert, the younger brother of King Saint Louis of France [Hahnloser 1972]. Later Gerevich has changed his reconstruction based on the results of his later excavations, particularly after the identification of the burial site in the transept of the abbey church. This reconstruction (Fig. 2) used the excellent documentation (including drawings and measurements) of the fragments made by Endre Egyed.

This work still offers an important information for more recent reconstructions [Takács 2014; Takács 2015]. Furthermore, in another reconstruction attempt, a physical 3D gypsum model was created by a sculptor, Vilmos Osgyányi [1985] (Fig. 3). He has used all the results of Gerevich and the documentation of Egyed. His chief design principles were based on procedures well-known and common in medieval art practice. He has utilized standard geometric patterns for identifying proportions and for the size of the monument's elements. Osgyányi has also contributed to our knowledge by identifying details of the carving process and by documenting still visible elements of the artistic creative process, which are also connected to present-day sculpting techniques.
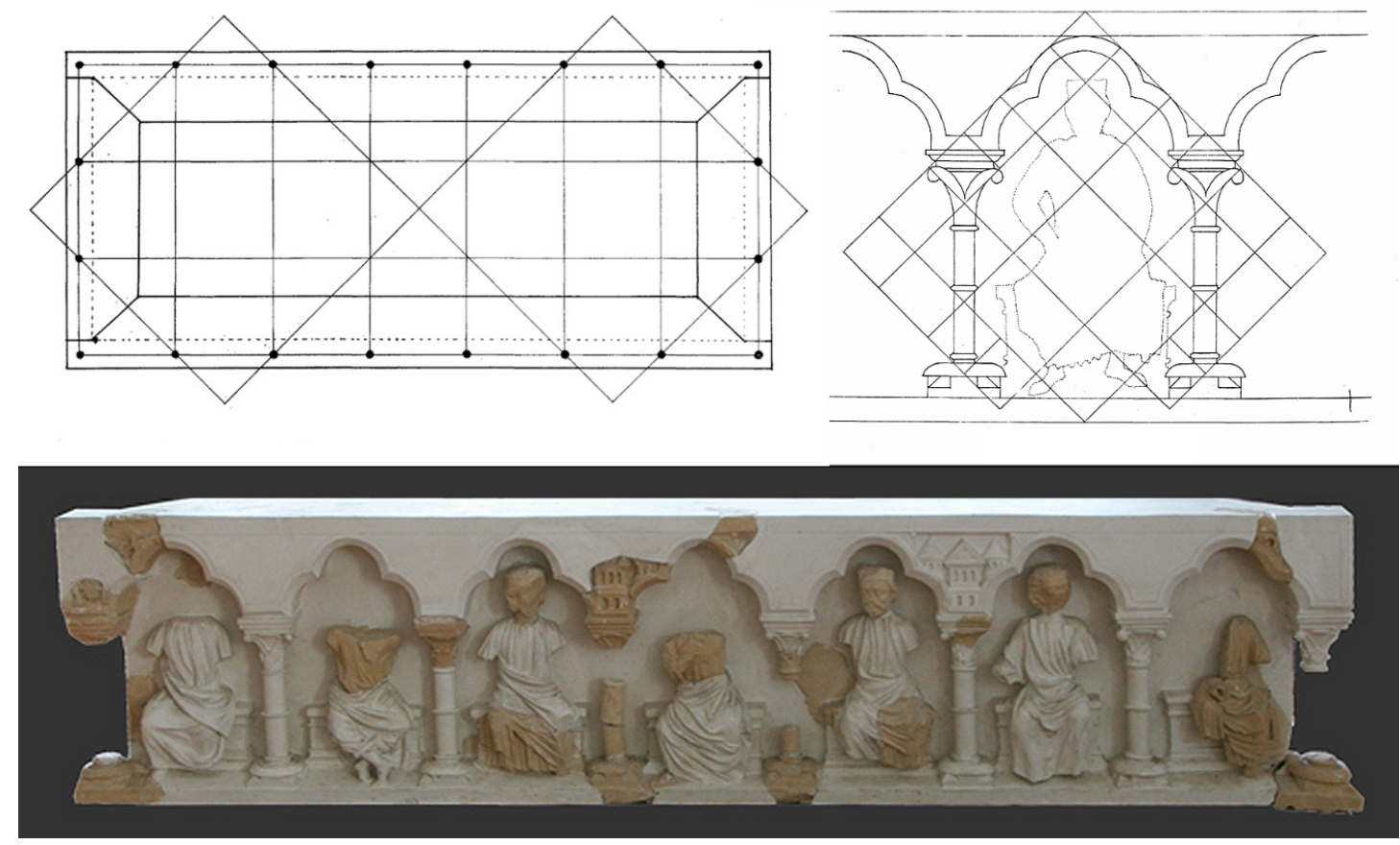

Figure 3. Designing principles and the full-size gypsum model by V. Osgyányi [1985]. Original fragments are indicated by colored copies of the carved pieces.

After these first reconstruction attempts, further carved stone elements of red limestone were connected to the same monument by Takács [Takács 1994] (Fig. 4). All other pieces were carved of fine sandstone (in some other publications they are described as grayish-yellow limestone) with traces of color painting and gilding. According to Takács, the whole monument was covered by polychrome decoration except the red limestone plates [Takács 1994; 2014; 2015]. He has also studied the broader art historical aspects of the monument and used a wide range of parallels for his reconstruction. 


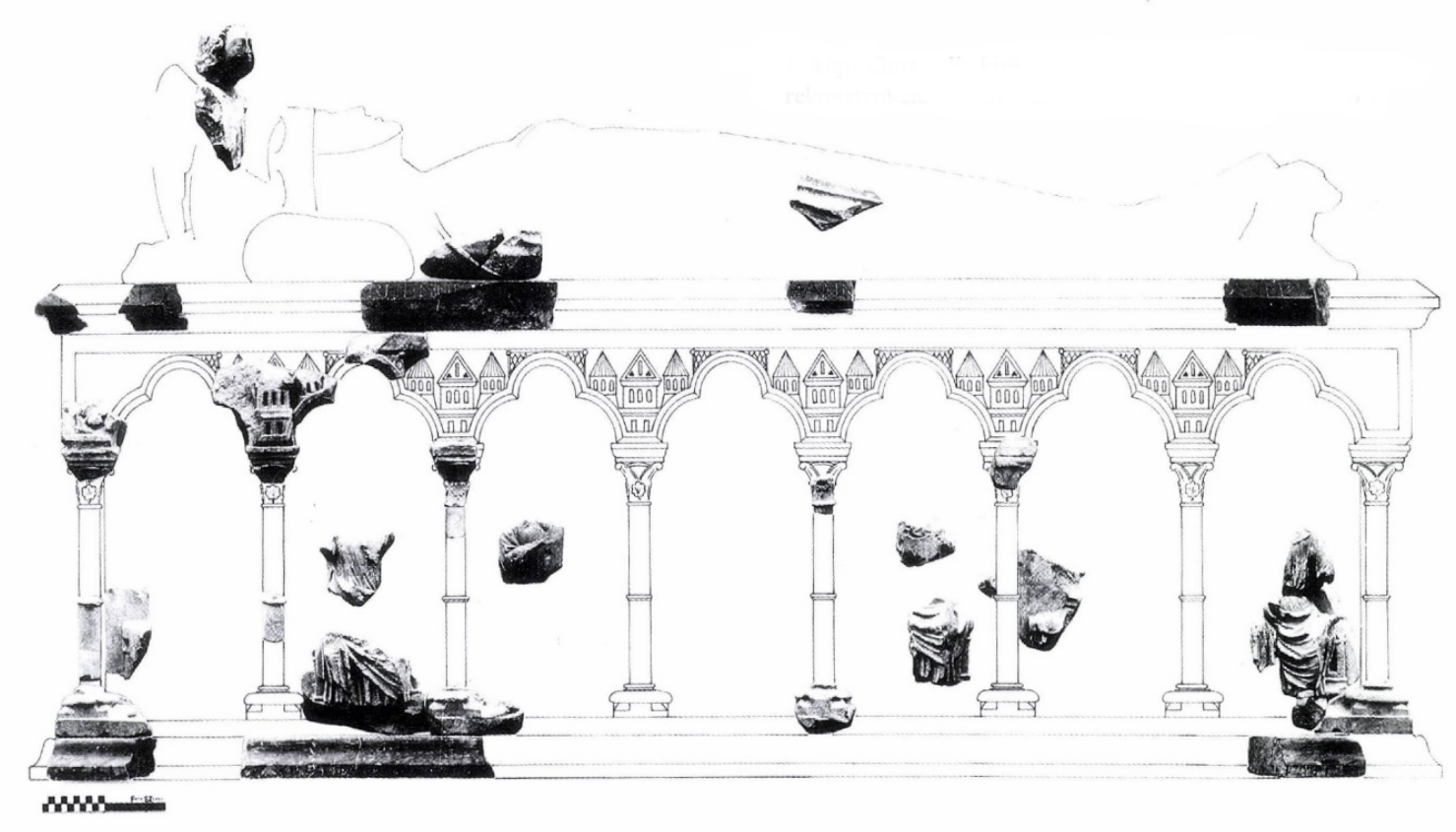

Figure 4. - The reconstruction by I. Takács [Takács 1994].

The present digital reconstruction project started in 2013, and the main survey work was carried out in that year. Parallel to this project Imre Takács continued his art historical studies and has published his new catalog of the carved stones and a new reconstruction with his major overview on the international connections of the monument. In the survey work phase of our present project the new results of Takács were not available, thus, our present study only reflects his new findings in some respects.

Here, it is our goal to present the new opportunities created by the digital technologies. They are mainly relevant for considering the extent to which the reconstruction process can be made transparent and available for other specialists. We are publishing them inspired by the same concept as Takács has summarized his results: "with the recovery of new finds and with new excavations, the currently known set of the finds of fragments may obviously increase, the details of the reconstruction may be modified, and our knowledge of the tomb may improve. Certainly, today answers are lacking for several questions, and the existing answers are also defective and incomplete. Not only is the road open to rectification and revision, but new ideas, critical reflections, and arguments are indispensable for the pursuit of this kind of work. Yet the work will hardly ever be 'finished'" [Takács 2015].

\section{ANALYSIS OF THE PREVIOUS RECONSTRUCTIONS}

Comparing all these previous reconstruction attempts, some general trends can be identified along with significant differences of the applied methods and results. In Imre Takács's art historical 
research [Takács 1994] the main concept of reconstruction is very similar to Gerevich's drawing, but the proportions of the tomb are different in his work. In the process of studying the fragments, two pieces of a column which joined were identified; accordingly, they were restored as parts of a single column. [Takács 1994; 2014]. This changed the proportions of the reconstruction. The reintegrated column fragments made the tomb higher in Takács's reconstruction. This is one of the elements of the new reconstruction where exact data and measurements support the different concept. Another important issue is the number of niches with sculpted decoration on the long and short sides of the monument. The number of niches on the long side turned out to be seven. Takács also explored some artistic influences of the epoch on the queen's burial monument and similar burial monuments were taken into consideration both in composition and in details of carving. In his most recent reconstruction [Takács 2015], a new version of the short sides of the monument has been proposed, one with a broad single trefoil niche and another with a double niche.

\section{OBJECTIVES OF THE NEW PROJECT}

The $800^{\text {th }}$ anniversary of the death of Gertrude offered an opportunity to investigate this outstanding relic of the High Middle Ages and to develop a 3D digital model to integrate and adjust former results [Russo and Guidi 2011 and Guidi et al. 2014]. This, however, forced us to confront a number of complex research problems. 43 of the 65 known fragments have been surveyed in the framework of the present 3D project. Processing the 3D survey data, thus, required an approach different from traditional ones. Therefore, we concentrated on three key questions raised by the new reconstruction process:

- How can digital technologies be combined with traditional methods?

- Can this approach facilitate collaborations between experts from different disciplines?

- Can scanning and high precision measurements reveal hitherto unnoticed features of the monument?

\section{3D DIGITAL RECONSTRUCTION}

\subsection{Survey and data processing}

Before creating a new 3D reconstruction of the monument, we collected archaeological and art historical findings and reconstructions. In this process, particular emphasis was given to the study of typological parallels concerning the tomb.

The first stage of the modeling process was the surveying of the full-size gypsum model of the monument and all the available fragments (Fig. 5). We used terrestrial laser scanner (Leica HDS 7200) to acquire the point cloud of the gypsum model. The aim of this measurement was to get a volumetric model on which the scale and proportions of the whole gypsum model can be studied. The Leica scanner provided us a suitable solution, with its $0.3 \mathrm{~m}$ minimum range and $0.1 \mathrm{~mm}$ resolution. 


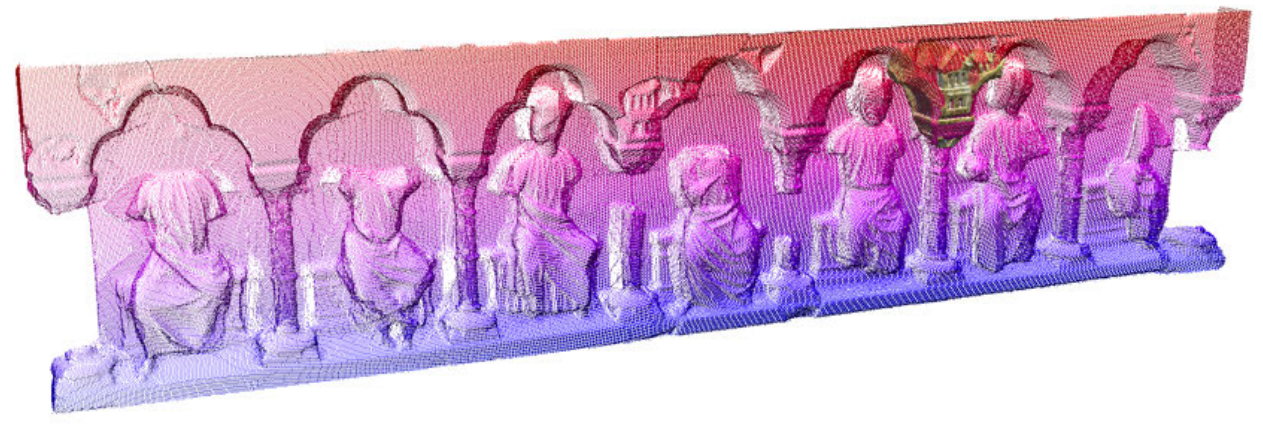

a)
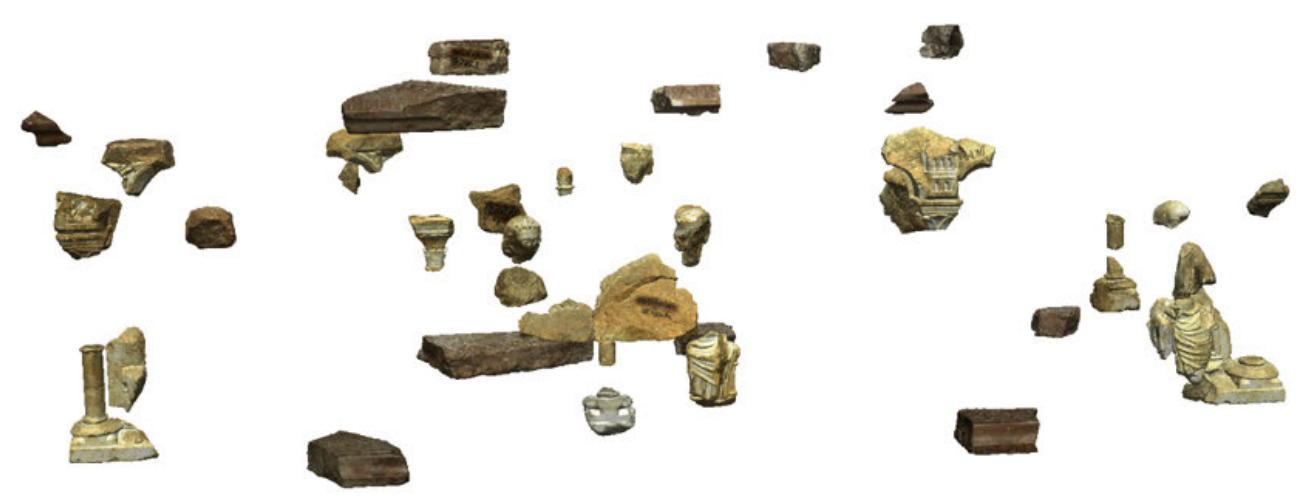

b)

Figure 5. The outputs of the survey: a) scanned image of the $3 d$ gypsum model; b) scanned images of the most important fragments.

The original fragments, however, were scanned with higher precision to detect all the details of their surfaces. Altogether, 43 pieces of carved stone fragments were captured by two types of structured light 3D devices.

The Breuckman Smart Scan 3D, with its 0.020-0.265 pixel size and 20-265 $\mu$ m resolution, provided us with highly precise models of the majority of the fragments. Owing to their state at the time of measurement, some fragments needed to be captured with different equipment. We therefore also used the Artec EVA. Even though this latter device provided us only 0,5 mm 3D resolution, the resulting mesh models were still sufficient for our reconstruction purposes.

\subsection{Modeling process}

In contrast to the traditional work process, there was no chance to study the fragments physically after their survey. Concerning scanned data organization, each fragment was represented by one separate file. 
In order to achieve smooth processing, we built up a simple database. The first one created (which became the main one) includes the different properties (i.e., presumed location, descriptions, and shape of fragments). The field values were 0 or 1 depending on whether the property was identifiable or not for the item. Besides data on the geometry, location, and references (secondary literature) of the fragments, the results of the consultations with various experts (art historians, archaeologists and architects) were also included in the database. The connection between the different parts of the database was achieved by the ID field of the fragments, i.e. their catalogue number in the museum (Fig. 6). Thanks to this information, most of the fragments could be connected to the tomb's architectural elements.

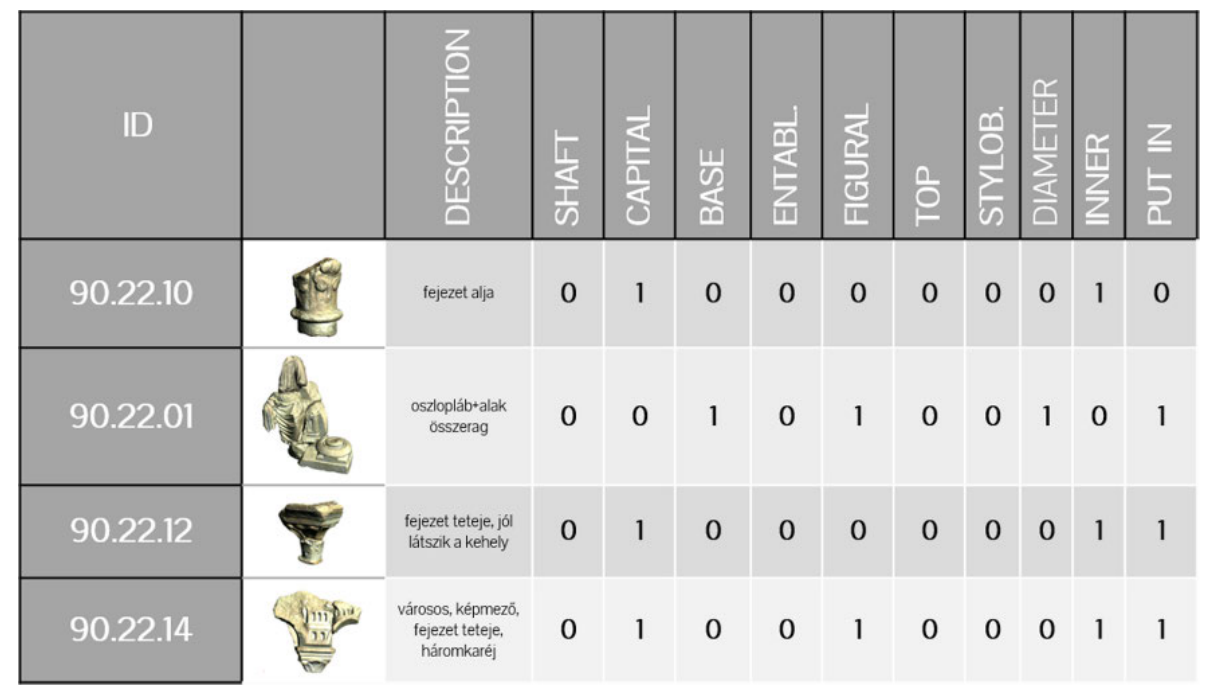

Figure 6. A part of the main table.

During the consultations with experts, the models in Adobe Acrobat 3D pdf format were primarily used, because in this format they were rotatable and measurable. This 3D pdf is not only suitable for visualization, but it is also very effective, as cross-sections are freely created and dimensions can be easily measured.

Even though this 3D visualization solution works solely using Adobe reader application, we realized that it was the most efficient way in sharing our finding with the contributing researchers of various fields.

Besides 3D pdf formats we generated obj and ply meshes, too, which can be analysed with open source 3D mesh processing tools, such as MeshLab. Furthermore, the textured reconstruction model was also generated as an obj format mesh.

The database grew as the modeling process was proceeding and the data content was updated with the new observations. At the same time, it remained relatively easy to create various query structures connected to different aspects of the database. 
In the initial stage of the project, the user-friendly format of 3D pdf was used for consultations. At the end of each phase of the modeling process, the current version of the model was saved to the database. Thus, the entire research process could be reconstructed, which allowed different directions for investigations.

Our 3D reconstruction was made based on all available data by applying the appropriate software. In order to make both the model variants (which were saved) and each step of the modeling process verifiable later, we used CAD and reverse engineering software. We applied Geomagic Design, AUTOCAD and Archicad software.

\subsubsection{Comparison of the new results with the previous reconstructions}

In the project, the virtual reconstruction was based on the aforementioned reconstruction concepts and design principles. However, at the same time, one of our main goals was to check all the elements of the previous reconstructions with the help of digital technologies (Fig. 7).
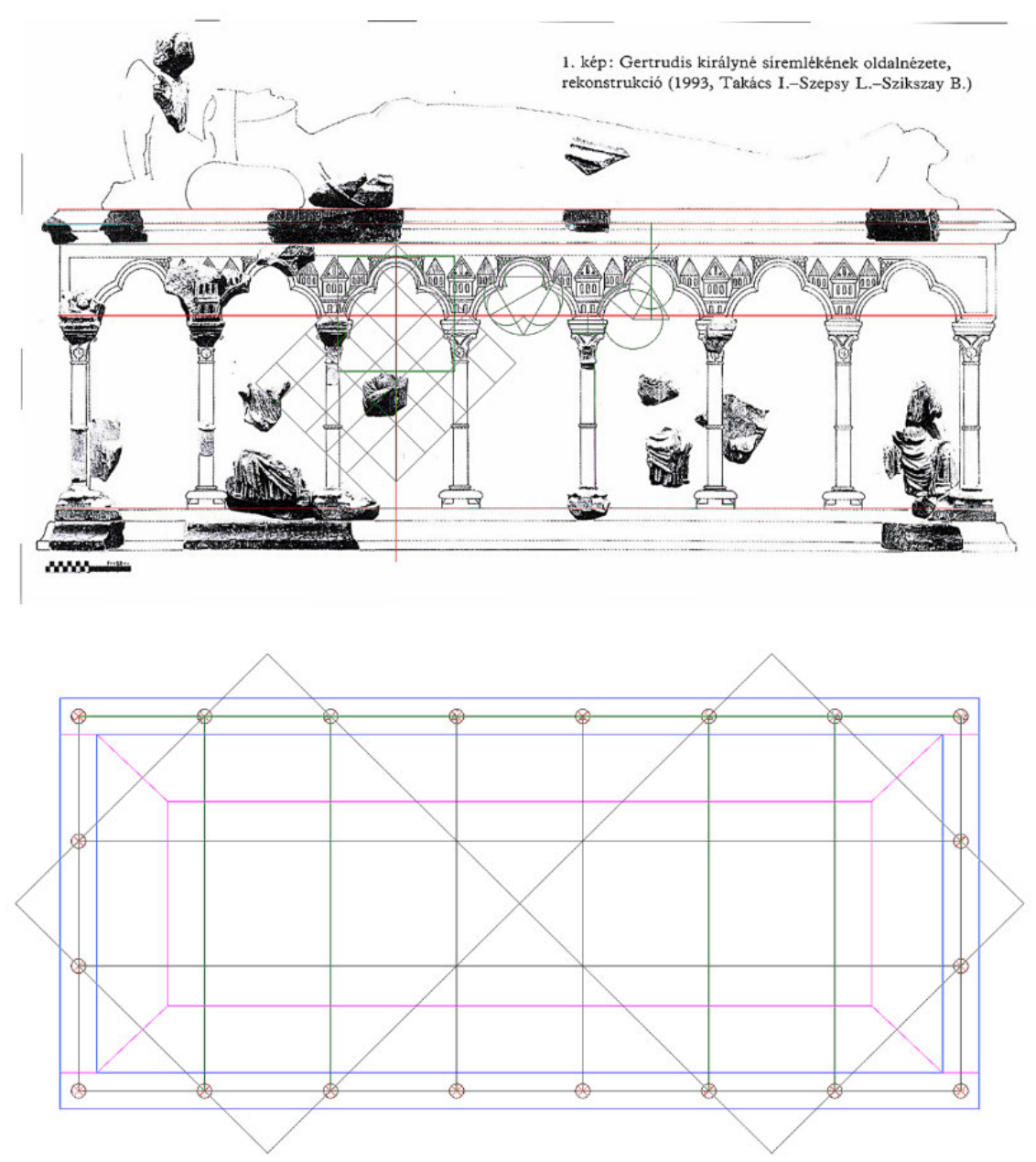

Figure 7. Studies for comparison. 
In order to evaluate the previous reconstructions and to work with their results, we had to digitize all the other available materials and sources.

The reconstruction drawings were transferred as raster, while the sculptured 3D model as a point cloud. In such cases, measurements were made with the help of the scale attached to images and numbers indicated in the chart below represent measurements as accurate as it was possible with the help of this method. The surface models were derived from the point cloud. The results of the reconstructions are shown in Table 1.

Table 1. Comparison of dimensions

\begin{tabular}{|c|c|c|c|}
\hline & Vilmos Osgyányi & Imre Takács & SziMe 3D \\
\hline $\begin{array}{l}\text { Distance between the } \\
\text { column shafts }\end{array}$ & $\begin{array}{l}\text { Measured average: } 29.1 \mathrm{~cm} \\
\text { published: } 28.4 \mathrm{~cm} \text { (p.605) }\end{array}$ & Measured average $28 \mathrm{~cm}$ & $\begin{array}{l}\text { Version 1: } 28.9 \mathrm{~cm} \\
\text { Version 2: } 30.9 \mathrm{~cm} \\
\text { see also Fig. } 9\end{array}$ \\
\hline $\begin{array}{l}\text { Diameter of the } \\
\text { column shaft }\end{array}$ & $\begin{array}{l}\text { Measured average: } \\
30.84 \mathrm{~mm}\end{array}$ & $\begin{array}{l}\text { Published: } 35 \text { mm [Takács 2014, } \\
\text { p.192.] }\end{array}$ & $\begin{array}{l}\text { Measured average for } \\
\text { corner column: } \\
35.8 \mathrm{~mm} \\
\text { measured average for } \\
\text { column: } 30.5 \mathrm{~mm}\end{array}$ \\
\hline Height of the columns & Measured: $14.3 \mathrm{~cm}$ & $\begin{array}{l}\text { Measured on the basis of } \\
\text { reconstruction drawing: } 25 \mathrm{~cm}\end{array}$ & $24.7 \mathrm{~cm}$ \\
\hline $\begin{array}{l}\text { Distance between the } \\
\text { plinth and the lid of the } \\
\text { monument }\end{array}$ & $49.2 \mathrm{~cm}$ & $\begin{array}{l}\text { Measured based on } \\
\text { reconstruction drawing: } 59 \mathrm{~cm}\end{array}$ & $58.2 \mathrm{~cm}$ \\
\hline Ratio of bays (niches) & $7: 3$ & $7: 1 ; 7: 2$ & $7: 3$ \\
\hline
\end{tabular}

\subsubsection{The four main steps of creating the virtual reconstruction}

\subsubsection{Defining the distance of the axes of the columns}

In terms of the new 3D model a fragment of the trefoil arch was the key element (Fig. 8). This piece helped to calculate the radius of the trefoil arch and the distance of the columns, which was $28.6 \mathrm{~cm}$ (Fig. 9), but one of the sculptured fragments and the figural part above the arch corrected this dimension to $31 \mathrm{~cm}$ (Fig. 10).

With this process, we could check the measurements of Endre Egyed with the help of several relevant fragments (Fig. 11). 


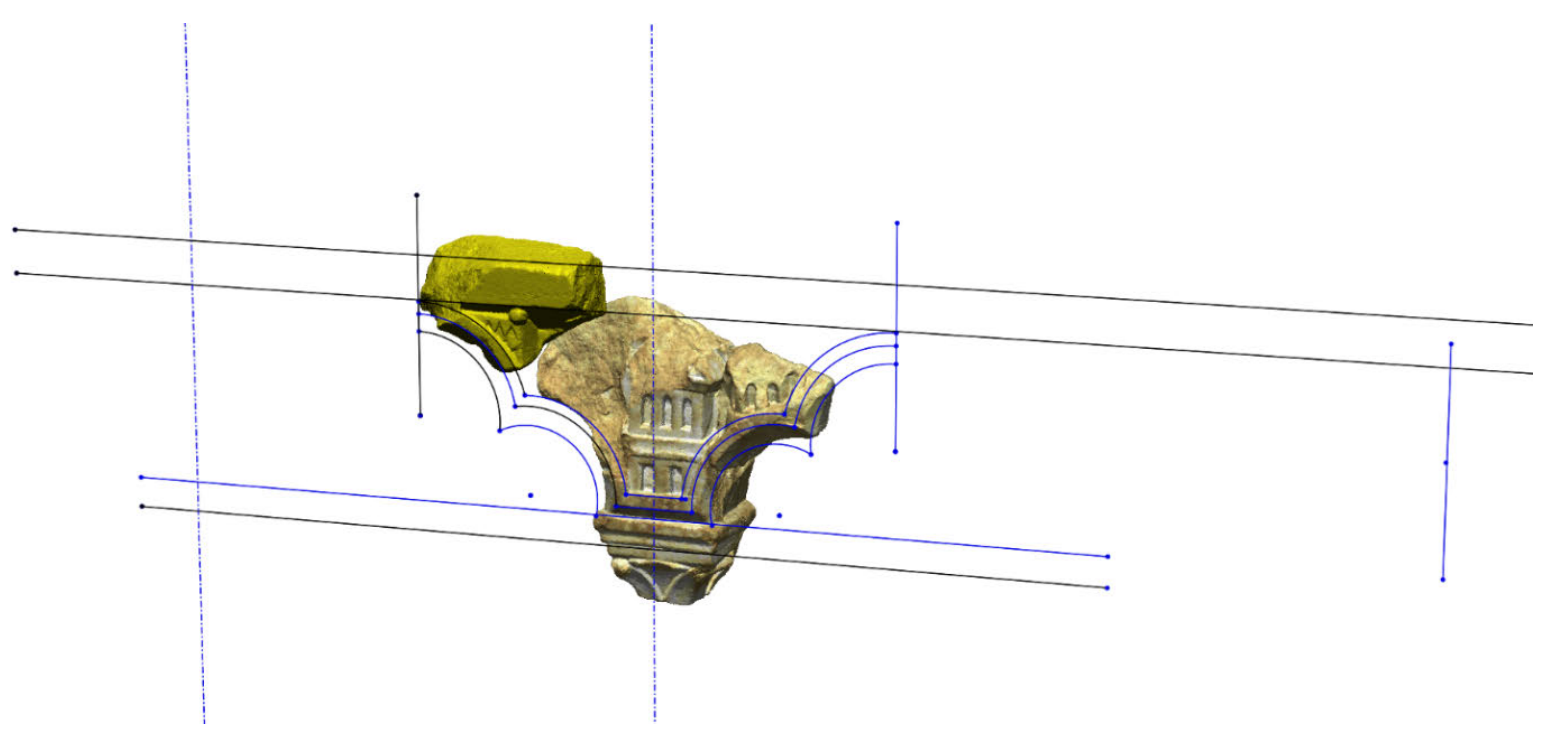

Figure 8. The key element.

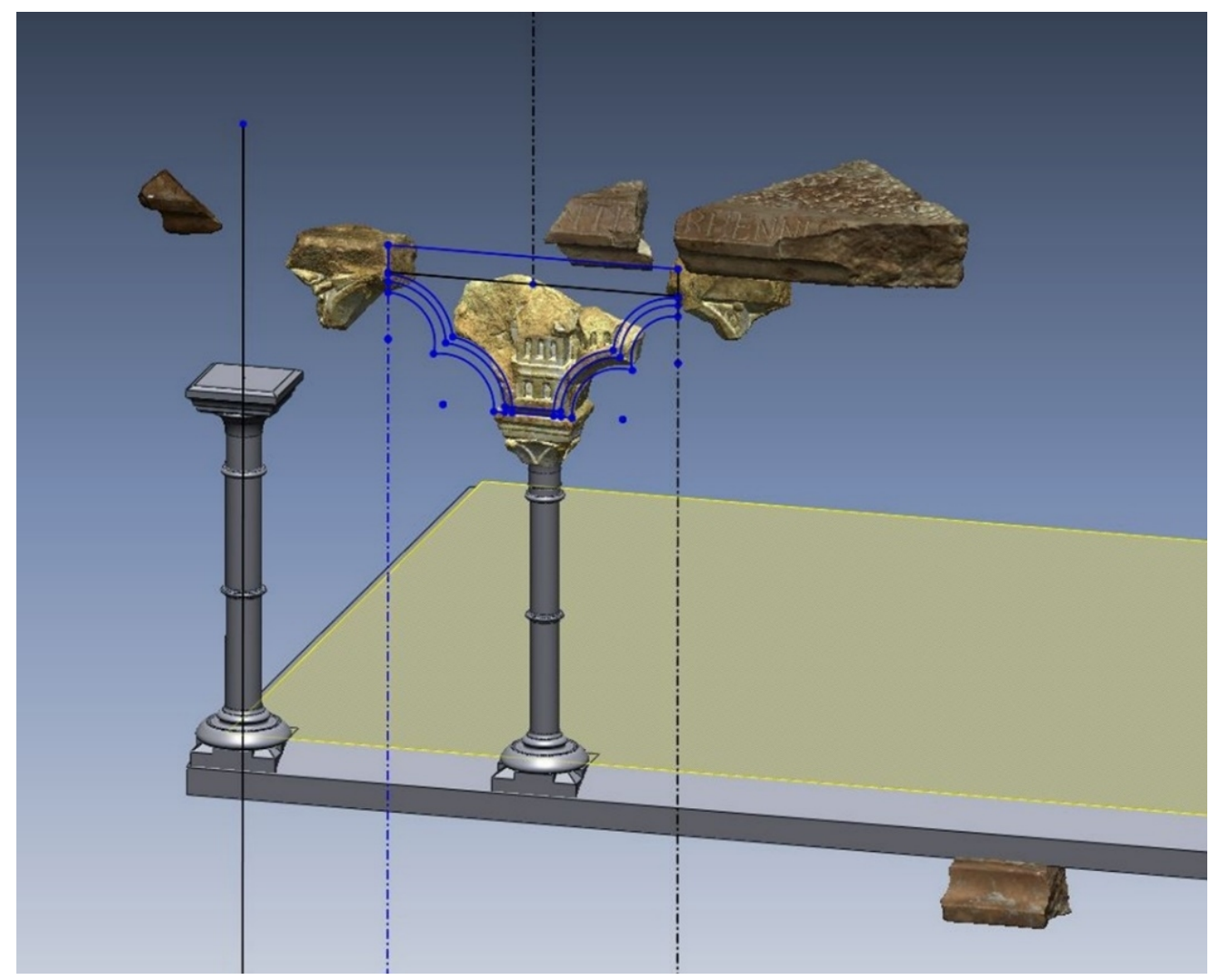

Figure 9. Distance between the columns with the key element. 
1:512 B. Szabó et al.

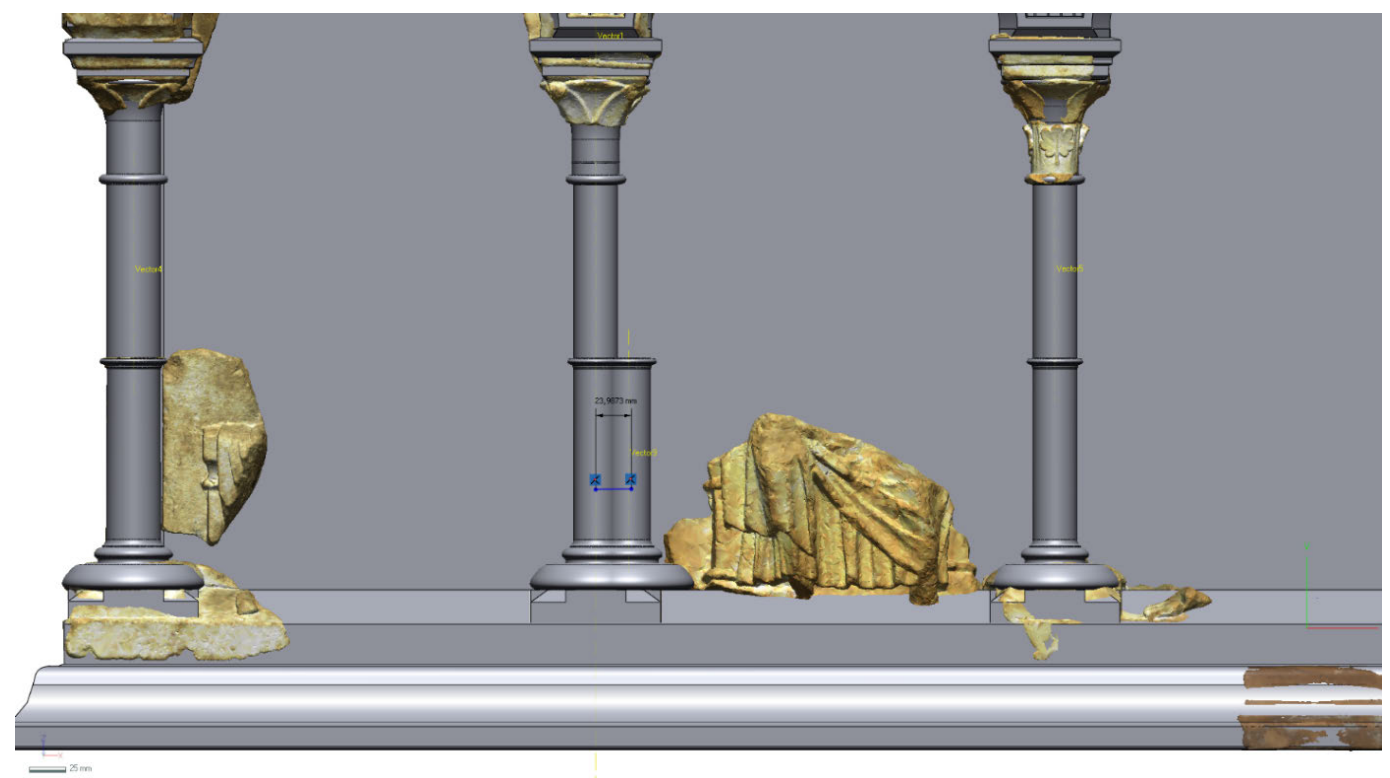

Figure 10. Modified distance between the columns in the new reconstruction. The size and position of a carved element changes the distance between the columns, previously only identified by the size of the reconstructed trefoil arch.

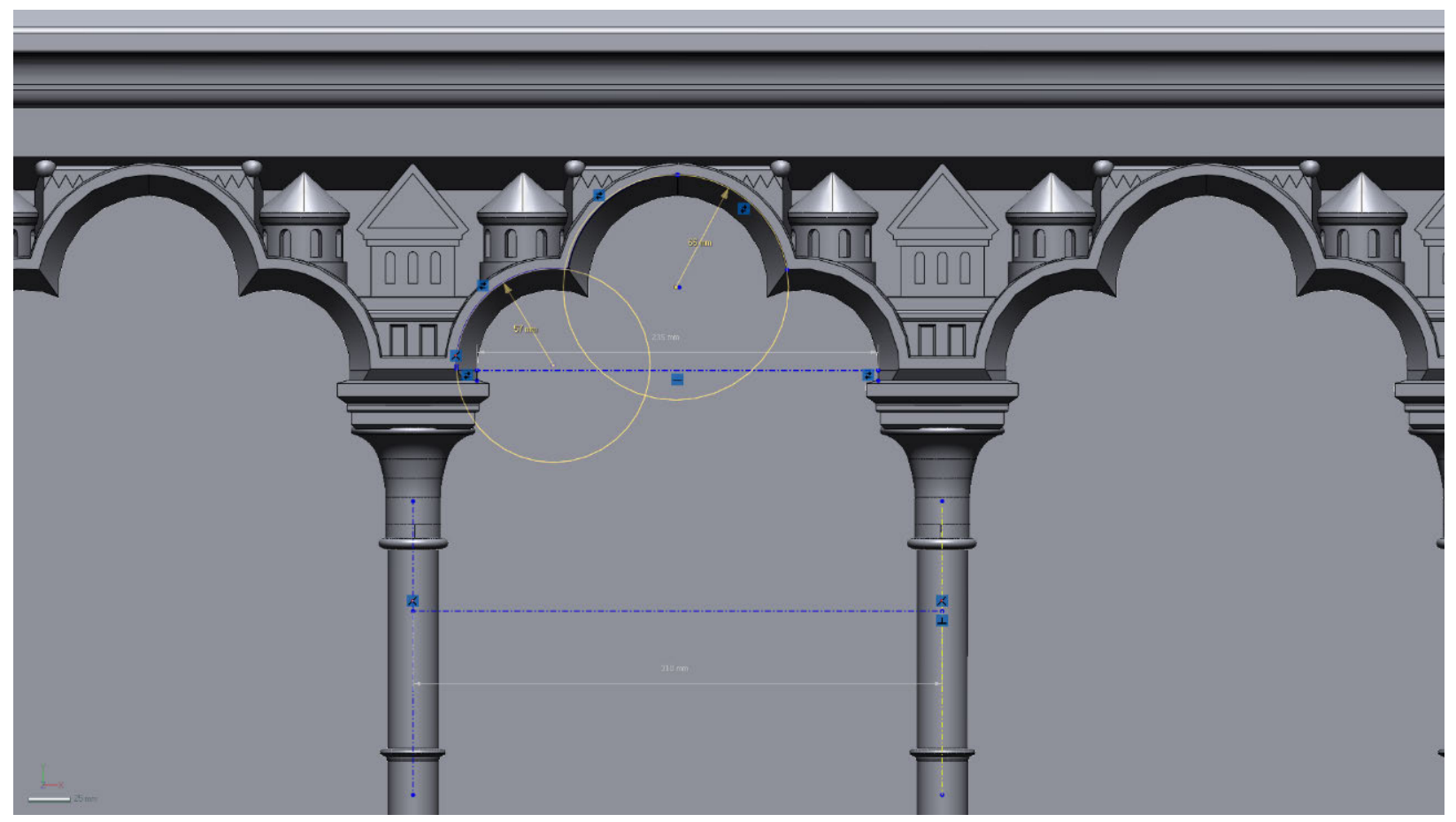

Figure 11. Modified distance between the columns in the new reconstruction and the main arch. 


\subsubsection{Height and diameters of the columns}

This difference can also be used as a distinctive element of the reconstruction, where columns on the corners of the burial monument were thicker compared to columns of the long sides (Fig. 12). Earlier reconstructions [Gerevich 1971a; Osgyányi 1985; Takács 1994] of the same elements did not use this difference in size. This element also confirms another aspect of the reconstruction by Takács, namely the high niches compared to earlier reconstructions. Furthermore, it has allowed us to check the vertical dimensions of the monument, again corroborating this aspect of the reconstruction by Takács.

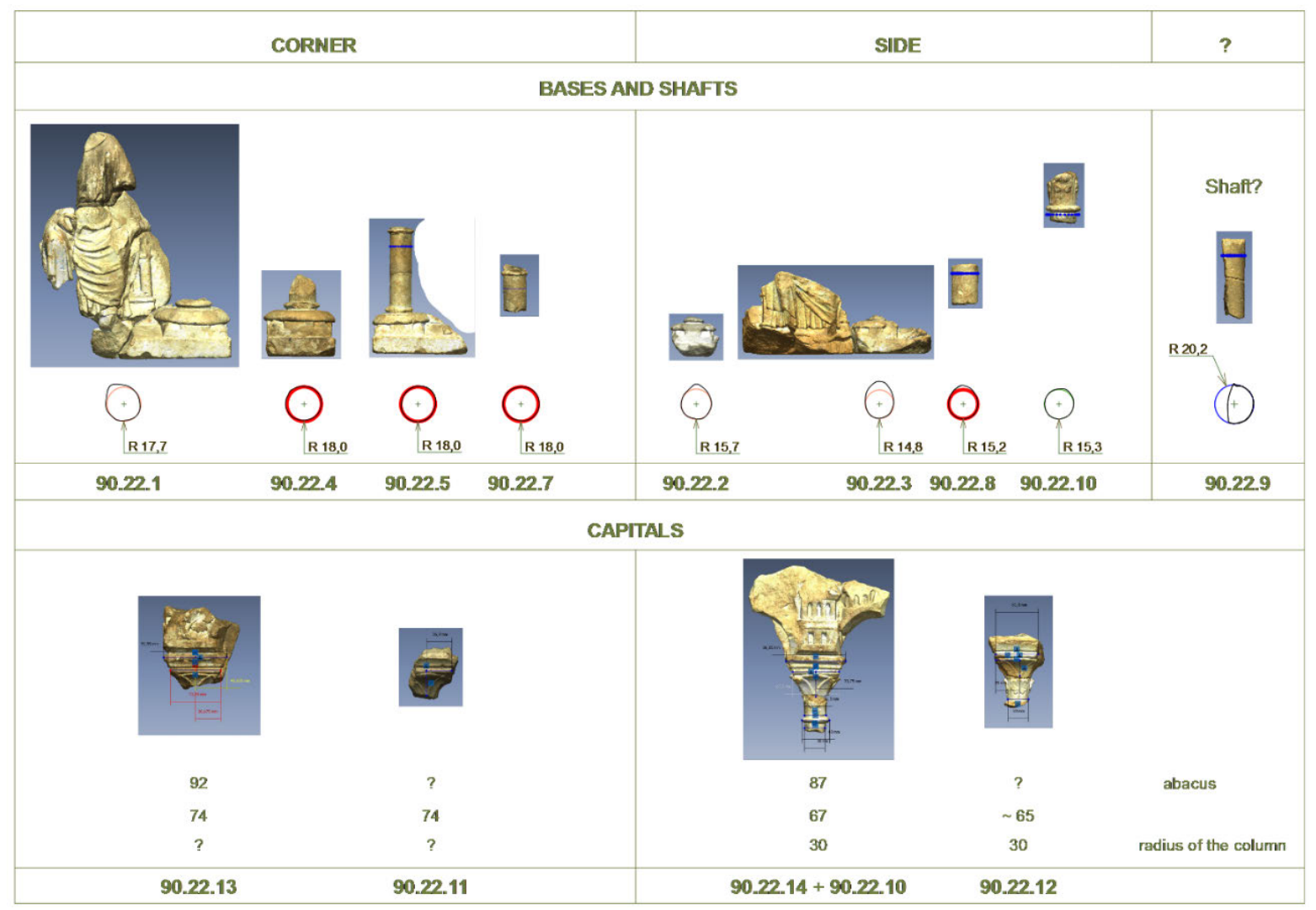

Figure 12. Dimensions and location possibilities of the columns.

\subsubsection{Determining the main profiles}

This phase required a generalization of the fragments. As a result of the high-resolution (structured light scanners could reach uncertainty up to 3 microns), we could work with life-like models. Available generalization can only be accomplished with shapes, where, besides typical features, individual characteristics can also be traced. As for the mold profiles of the tomb, they were reconstructed by averaging the parameters of the fragment profiles using art historical analogies. This way profiles of the lid and pedestal could also be generated. 
1:514 B. Szabó et al.

\subsubsection{The size of the sepulchre}

To define the size of the tomb, the distribution of niches situated on each side were examined and compared to the dimensions of the grave. Imre Takács already referred to the excavation results and to the drawing of the grave [2014], but additional features could also be taken into account. By using the new measurements and the survey of the individual fragments, the size of the long side can be identified with a higher accuracy, and it can also be compared to the short side of the monument. In this way three models were set up with 1 to 5,3 to 7 , and 1 to 6 niche ratio bay proportions. (Fig. 13) Although we acknowledge that the connection between the grave structure (masonry) and the burial monument is questionable, in the present situation there is no way to solve this problem. Thus, the reconstruction of the burial monument should take into consideration the excavation results related to the masonry of the grave. Takács has already convincingly argued that the majority of fragments came from the area of the grave [Takács 2014] and the critical evaluation of the excavation data also supports this hypothesis [Benkő 2014; Laszlovszky and Szentpéteri 2014]. In his 2015 reconstruction, he has offered another solution, which shows very different proportions [2015] The size of the grave pit and its masonry, however, suggests a different solution with different proportions, indicated in the present study. Final answer, however, can only be determined for this complex question by a new control excavation of the site.
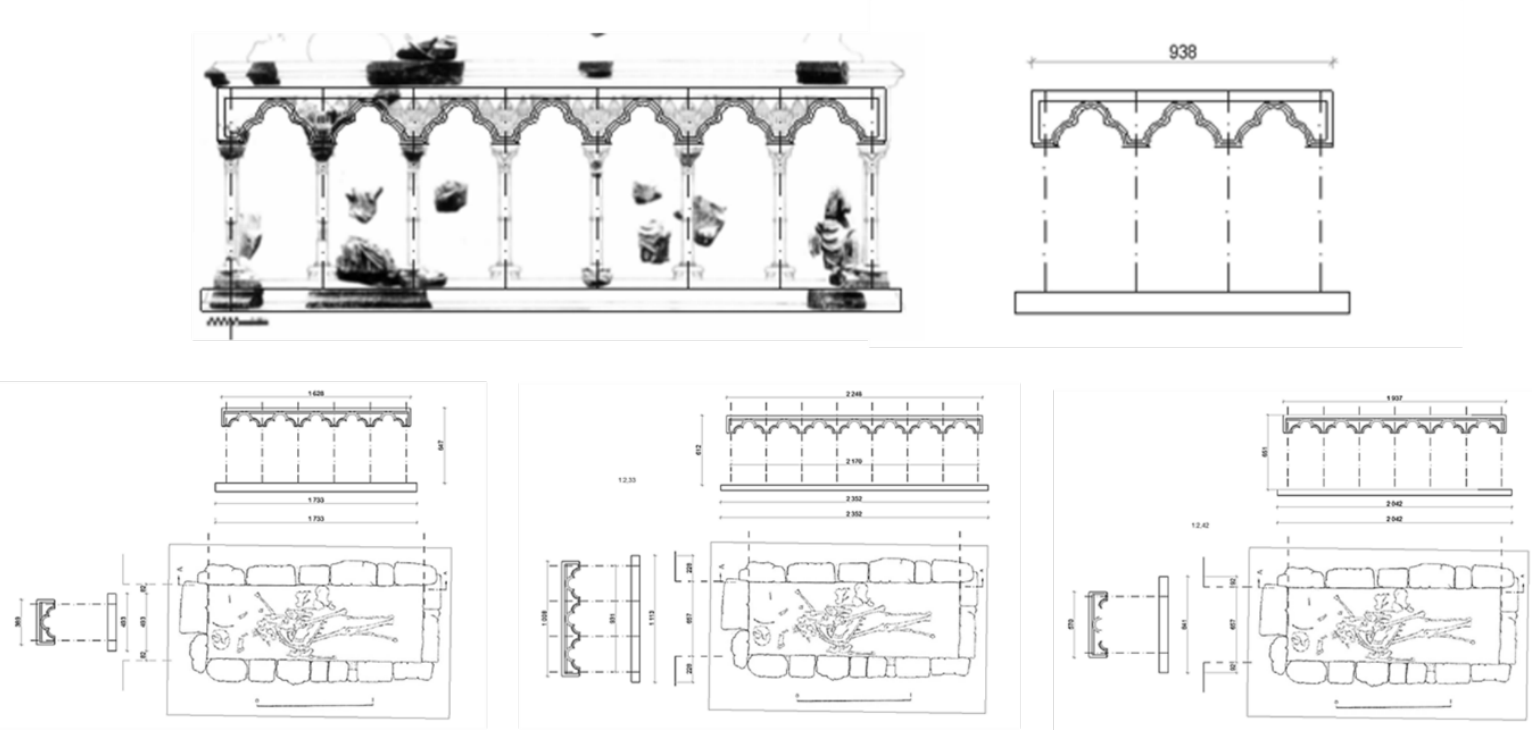

Figure 13. Bay proportions and relations between the tomb and the grave.

The new attempted reconstruction offers not only new solutions concerning the size and proportions of the monument, but it also creates new images for various aspects of the process of reconstruction. With the help of these, new results can also be derived from our digital approach. The oblique plan above the arch (Fig. 14) was missing in the previous reconstructions, but it can be clearly derived from the modeled fragments. In this respect, it can be stated that only minor differences appear in the present reconstruction as compared to previous attempts. At the same time, methodological conclusions related to the reconstruction process can also be formulated based on these elements. 

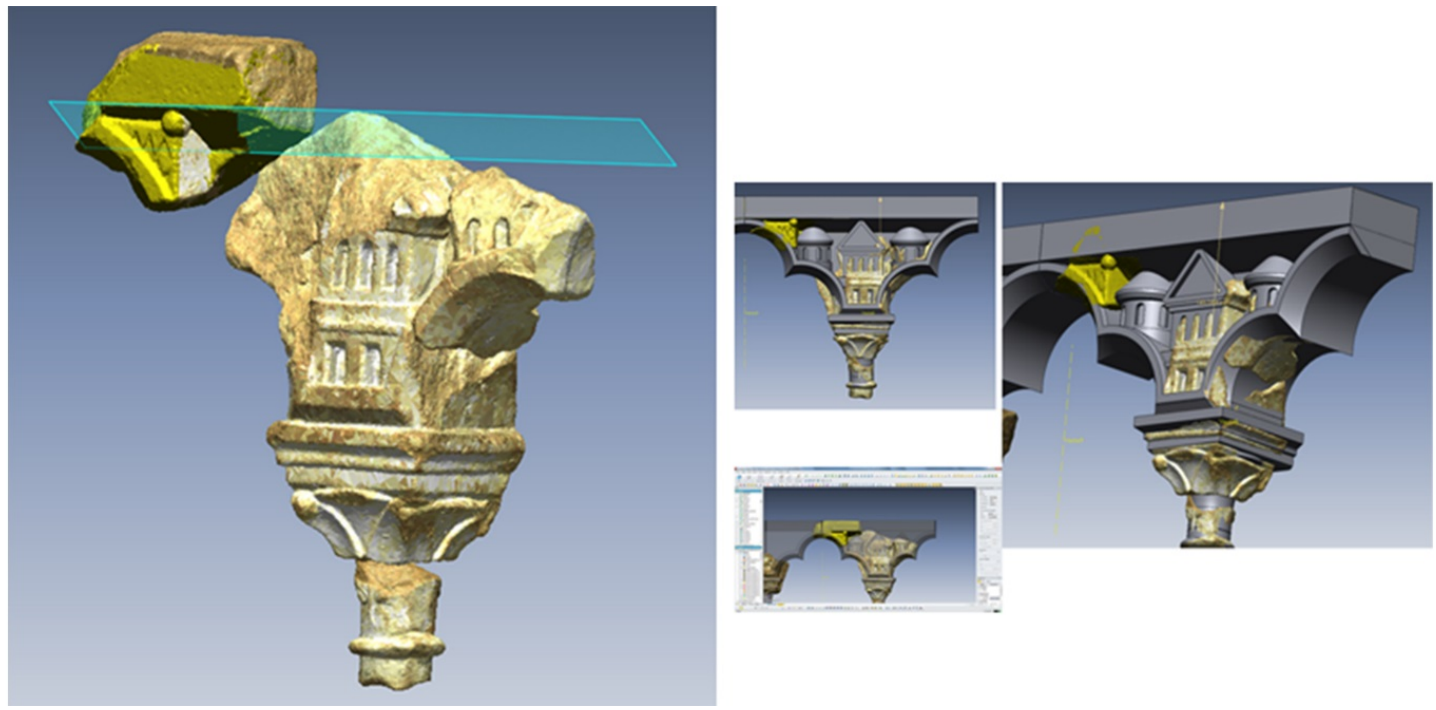

Figure 14. The slant plan.

\section{DISCUSSION}

The new 3D model (Fig. 15) is only one of the possible ways to reconstruct a destroyed monument from fragments. Given that the available set of the fragments is rather incomplete, newly found fragments may modify the results and conclusions of former reconstructions. An advantage of our digital model over previous ones is that new fragments can easily be incorporated into the present model and their authenticity can be tested more effectively. Furthermore, alternative reconstructions or additional features can be easily created. This option was obviously unavailable in terms of the previous 3D gypsum model. Due to detailed documentation of individual stages, according to the recommendations of the London Charter [2009] the modeling process can be controlled and the links between various professional fields and editing phases can be retraced.

Thus, we did not include the high-relief figures which appeared in earlier reconstructions [Takács 1994] onto the cover of the monument. Omitting these details could be justified by the fact that only two of fragments, supposedly illustrating drapery, belonged to this fragment group. On the other hand, we had no opportunity to scan the figures of angels seen in the Gerevich and Takács reconstructions. Some fragments, whose identification or connection to the other fragments was dubious, were also disregarded. Thus, there is only one fragment safely identified as an element of the short side of the monument. So, this side represents only the aspect ratio of the tomb. Finally, this digital virtual reconstruction is able to function as an appropriate tool for scholarly research. The final product, the digital 3D model can be available for scholars. Details can also be controlled and the whole reconstruction process is available. 


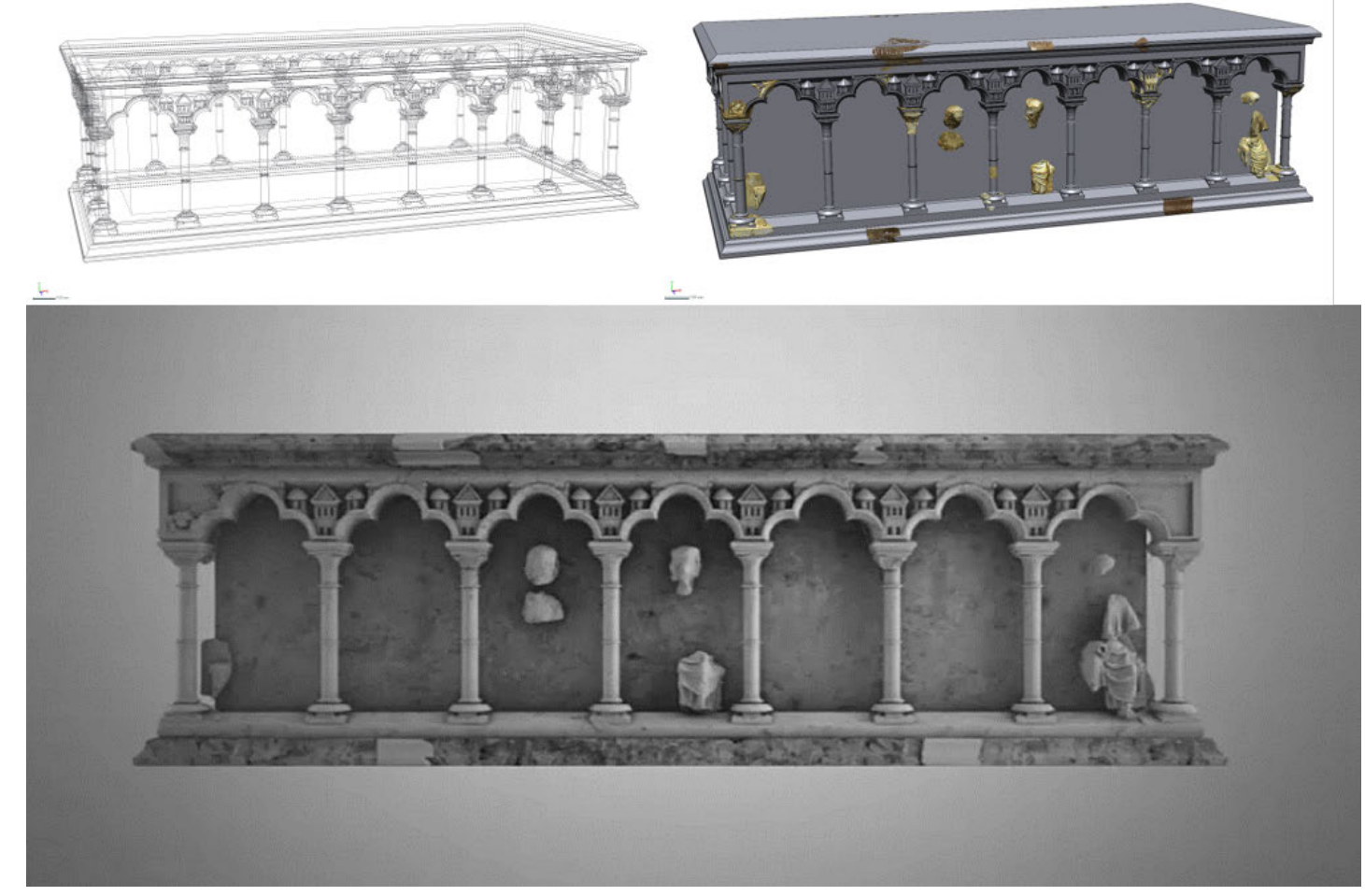

Figure 15. The different forms of the final model.

\section{ACKNOWLEDGEMENTS}

This research was funded by the European Regional Development Fund and the Hungarian Government (GOP-1.2.1-11-2012-0005) titled SziMe 3D [2013] launched by Humansoft Ltd. to survey and analyze buildings and objects with 3D scanning technology. The further goal of this project was to utilize new 3D technologies in the fields of tourism, education and sport.

The textured model and the animation were created by the Pazirik Ltd. This product is also available in a mobile application which can be used by the wider public.

\section{REFERENCES}

Elek Benkő. 2014. Gertrúd királyné sírja a pilisi ciszterci monostorban. In Egy történelmi gyilkosság margójára: Merániai Gertrúd emlékezete, 1213-2013. Szentendre: Ferenczy Múzeum, 173-188.

László Gerevich. 1971a. A gótikus klasszicizmus és Magyarország. Magy. Tudományos Akadémia Filozófiai és Történettudományi Osztályának Közleményei 20., 1-2. (1971), 55-72.

László Gerevich. 1971b. Villard de Honnecourt Magyarországon. Múvészettörténeti Értesítő 20. (1971), 81-105.

László Gerevich. 1985. A pilisi ciszterci apátság. Stud. Com. 17. (1985), 541-545. 
Gabriele Guidi, Michele Russo and Davide Angheleddu. 2014. 3D Survey and Virtual Reconstruction of archeological sites. Digit. Appl. Archaeol. Cult. Herit. 1 (2014), 55-69. doi:10.1016/j.daach.2014.01.001

Hans R. Hahnloser. 1972. Villard de Honnecourt. Kritische Gesamtausgabe des Bauhüttenbuchs Ms. fr. 19093 dér Pariser Nationalbibliothek, Graz: Akademische Druck.

József Laszlovszky and József Szentpéteri. 2014. "...Scripta manent”. Emlékképek a pilisi úgynevezett Gertrúd-sír megtalálásának körülményeiről. In Judit Majorossy, ed. Egy történelmi gyilkosság margójára : Merániai Gertrúd emlékezete, 1213-2013. Szentendre: Ferency Múzeum, 163-172.

József Laszlovszky and József Szentpéteri. 2014. "...Scripta manent”. Emlékképek a pilisi úgynevezett Gertrúd-sír megtalálásának körülményeiről. In Judit Majorossy, ed. Egy történelmi gyilkosság margójára: Merániai Gertrúd emlékezete, 1213-2013. Szentendre: Ferency Múzeum, 163-172.

London Charter. (2009). Retrieved October 1, 2016 from http://www.londoncharter.org/

Vilmos Osgyányi. 1985. Kőszobrász-restaurátori megfigyelések a pilisi Gertrudisz-síremlék töredékeinek rekonstrukciós feldolgozásához. Régészeti tanulmányok Pest megyéből, Studia Comitatensia(17.), pp. .. Takács, I., . Getrudis királyné síremléke. In: Á. Mikó \& I. Takács, szerk. Régészeti tanulmányok Pest megyéból Studia Com, 17 (1985), 603-619.

Michele Russo and Gabriele Guidi. 2011. Diachronic 3D reconstruction for lost cultural heritage. In Remondino, ed. 4th International Workshop 3D-ARCH 2011. ISPRS, Trento, Italy, 1-6. doi:10.2423/i22394303v1n2p71

Szime 3D (2013). Retrieved January 20, 2017 from http://szime3dar.com/en/

Imre Takács. 1994. Getrudis királyné síremléke. In Árpád Mikó \& Imre Takács, eds. Pannonia Regia, Múvészet a Dunántúlon 1000-1541. Budapest: Magyar Nemzeti Galéria, 248-256.

Imre Takács. 2014. A Gertrúd - síremlék rekonstrukciójának kérdései. In Judit Majorossy, ed. Egy történelmi gyilkosság margójára : Merániai Gertrúd emlékezete, 1213-2013. Szentendre: Ferenczy Múzeum, 189-202.

Imre Takács. 2015. The tomb of Queen Gertrude. Acta Hist. Artium 56 (2015), 5-88.

Received March 2017; revised July 2017; accepted August 2017.

Studies in Digital Heritage, Vol. 1, No. 2, Publication date: December 2017 